\title{
FGFR3 Gene Mutation
}

National Cancer Institute

\section{Source}

National Cancer Institute. FGFR3 Gene Mutation. NCI Thesaurus. Code C39877.

A change in the nucleotide sequence of the FGFR3 gene. 